\title{
Management of diabetic individuals with emphasis on prevention of foot amputation
}

M. Korintušová, V. Kozoň, E. Zacharová

Original Articles

St. Elizabeth University of Health and Social Work in Bratislava, Ph.D. Programm, Slovak Republic

\section{Correspondence to:}

St. Elizabeth University of Health and Social Work, Department of Social Work in Skalica, Nám. slobody 3, P. O. Box 104, 810 00, Bratislava, Slovak Republic

Submitted: 19.2 .2016

Revised: 5.7 .2016

Accepted: 4.8 .2016

\section{Reviewers:}

I. Bartosovic

Tropic team of st. Elizabeth, Slovak Republic

V. Okoth

Adjunct lecturer Catholic University of Eastern Africa

\section{Key words:}

Diabetes mellitus, diabetic, quality of life, preventive measures.

CSWHI 2016; 7(2): 70-80 @ 2016 Clinical Social Work and Health Intervention

\section{Abstract:}

Goal: The purpose of this work was to determine whether the duration of the disease in diabetic patients and their age have an effect on the quality of their life in relation to this disease. Determine the preference in measures aimed at the prevention of the diabetic foot complications in diabetic patients. Methods: The research population included 172 patients from Trenčín region in Slovakia. The research was based on a questionnaire developed by amending the standardized questionnaire of the WHO - WHOQOL-BREF to include additional items focusing on the choice of preventive measures related to the prevention of the complications of a diabetic foot. Results: No association was demonstrated between the duration of the disease in diabetic patients and their quality of life. However, the results demonstrated that there is an association between the age of the patients and their quality of life. We also found statistically significant differences in the choice of the most important areas of preventive measures preventing the complications of diabetic foot between men and women. 
Conclusion: Diabetic patients are not only passive recipients of care but also individuals who are active, independent and jointly responsible for the achieved results. Very important aspect is the knowledge of the preventive measures focused especially on the prevention of the complications of diabetic foot.

\section{Introduction}

Diabetes mellitus (DM) is one of the frequent, medically serious and high-cost chronic diseases. As a result of acute and chronic complications, this condition significantly contributes to morbidity, mortality and poor quality of life of patients.

An important means to improve the quality of life of diabetic patients, is their effective education and knowledge of preventive measures. Through education, diabetic patients are expected to become co-authors and be jointly responsible for the proper control of diabetes, thus contributing to the improvement of their quality of life (Holmanová, 2002, p. 53-54).

A much feared chronic complication of diabetes mellitus is the diabetic foot syndrome (DFS). Fard et al. (2007, p. 1931) claim, that up to $20 \%$ of diabetic patients are hospitalized with DFS. The World Health Organization defines DFS as the ulceration or destruction of deep tissues of the foot associated with neurological abnormalities and varying degrees of ischaemia. Diabetic ulcerations affect $15 \%$ of diabetics during their life and they also represent a risk of amputation of the affected part of the foot, with prevalence of $0.5-1 \%$ of diabetics. More than $85 \%$ of amputations in diabetics are accelerated by the development of ulcers, infection and gangrene (Jirkovská, 2006 , p. 297). The education of diabetics and their families is an integral component of the nursing process, a systematic and rational method of providing care.

\section{Objectives}

The objective of the work was to contribute to the improvement in the area of care for patients with diabetes with emphasis on the prevention of foot amputations and to assess their quality of life and their position on preventive measures. This objective was split in two tasks:

1. Determine whether the duration of the disease in diabetic patients and their age have an effect on the quality of their life in relation to this disease.

2. Determine the preference in measures aimed at the prevention of the diabetic foot complications in diabetic patients.

\section{Methods}

In the research project we focused our attention on the specification of the differences in the perception of the quality of life of people with diabetes and on the assessment of the preventive measures from the viewpoint of certain sociodemographic factors.

The subject matter of the research was the perception of the quality of life in 
people with diabetes and preference of preventive measures with respect to the prevention of diabetic foot complications.

The object of the research were the patients with diabetes in selected out-patient diabetology practices in Trenčín region in Slovakia. The research population consisted of 172 subjects. Data was collected using a questionnaire consisting of two parts. In the first part of the questionnaire, the subjects assessed their quality of life using an independent standardized questionnaire of the World Health Organization WHOQOL-BREF containing 26 items, where two separate items were related to the overall evaluation of the quality of life and satisfaction with health and 24 items were grouped in four domains (physical health, psychological health, social relations and environment). The results of WHOQOL-BREF are expressed in four domain scores, and a mean gross score for the two separate items, assessing the overall quality of life and health. The rating scale for individual items is $1-5$ and for domains 4-20. This part of the questionnaire was evaluated using the method of the authors of the standardized questionnaire Dragomirecká, Bartoňová (2006).

In the second part of the questionnaire, the subjects responded on preventive measures related to the prevention of diabetic foot complications. The subjects had the opportunity to choose 5 out of 16 areas of prevention that they consider the most important from the viewpoint of prevention of complications of a diabetic foot.

The questionnaire was also used to acquire identification and demographic information from the subjects - age, gender, highest achieved education and approximate diagnosed duration of diabetes. The data from the subjects was processed and analysed using mathematical-statistical methods at the level of descriptive and inductive statistics.

\section{Results}

Out of 172 subjects who were included in the research, 110 were women (64\%) and 62 were men (36\%). From the viewpoint of the highest achieved education, the largest was the subgroup with high-school education - consisting of 106 subjects (61.6\%), 44 subjects (25.6) had elementary education and 22 subjects (12.8\%) had university education. With respect to age, the subjects were divided into five subgroups. Subgroups aged below 40 years included 24 subjects (14\%), 41-50 years: 18 subjects (10.5\%), 51-60 years : 26 subjects (15.1\%). Most numerous were the subgroups 61-70 years $(33.7 \%)$ and $70+$ years $(26.7 \%)$.

The subjects had the opportunity to record in the questionnaires the approximate diagnosed duration of the disease - by marking one of the four ranges ( $0-5$ years, 6-10 years, $11-15$ years and $15+$ years). According to the responses, $56(32.5 \%)$ had been diagnosed with this condition for up to 5 years, 59 subjects (34.3\%) 6-10 years, 29 subjects $11-15$ years and 28 subjects $(16.3 \%)$ stated that they have been diagnosed with the condition for more than 15 years.

With respect to the defined partial objectives, the research results can be summarized into two areas:

\section{Quality of life of the patients with diabetes}

Table 1 presents the mean score of 26 items of this part of the questionnaire for our research population $(\mathrm{N}=172)$ and mean score of the set of individuals selected from standard population (marked *) according to the authors Dragomirecká, Bartoňová (por. 2006, p.22). Pilot testing was carried out on a research sample of 310 subjects, of which 161 were women (51.94\%) and 149 men $(48.06 \%)$ aged 18 to 58 years, whereas 
$8 \%$ of subjects were considered ill in this population. It is necessary to point out that this was a Czech population as no results of a similar research have so far been published in the Slovak Republic. However, we expect that the circumstances regarding this are similar in the Czechia and in Slovakia.

The first two items (marked as Q1 and Q2) are independent items related to overall assessment of the quality of life and satisfaction with health. For all two items, the subjects in the research

Table 1 Mean score for individual items for the research population and for standard population

\begin{tabular}{|c|c|c|c|c|c|c|c|c|}
\hline & Item & Question & $\mathbf{N}$ & Mean & SD & $\mathbf{N}^{*}$ & Mean* & SD ${ }^{*}$ \\
\hline 1. & Q1 & How would you rate your quality of life? & 172 & 3.22 & 0.83 & 310 & 3.82 & 0.72 \\
\hline 2. & Q2 & How satisfied are you with your health? & 172 & 2.77 & 0.88 & 310 & 3.68 & 0.85 \\
\hline 3. & q3 & $\begin{array}{l}\text { To what extent do you feel that physical } \\
\text { pain prevents you from doing what you } \\
\text { need to do? }\end{array}$ & 172 & 2.91 & 0.97 & 310 & 4.03 & 1.05 \\
\hline 4. & $\mathrm{q} 4$ & $\begin{array}{l}\text { How much do you need any medical } \\
\text { treatment to function in your daily life? }\end{array}$ & 172 & 2.61 & 1.07 & 310 & 4.16 & 0.95 \\
\hline 5. & q5 & Do you enjoy life? & 172 & 3.43 & 1.23 & 310 & 3.83 & 0.90 \\
\hline 6. & q6 & $\begin{array}{l}\text { To what extent do you feel your life to be } \\
\text { meaningful? }\end{array}$ & 172 & 3.62 & 1.13 & 310 & 3.86 & 0.85 \\
\hline 7. & q7 & How well are you able to concentrate? & 172 & 3.27 & 0.94 & 310 & 3.55 & 0.88 \\
\hline 8. & q8 & How safe do you feel in your daily life? & 172 & 3.20 & 0.96 & 310 & 3.24 & 0.79 \\
\hline 9. & q9 & $\begin{array}{l}\text { How satisfied are you with the } \\
\text { environment where you live? }\end{array}$ & 172 & 3.20 & 1.00 & 310 & 2.85 & 0.92 \\
\hline 10. & q10 & $\begin{array}{l}\text { Do you have enough energy for everyday } \\
\text { life? }\end{array}$ & 172 & 2.98 & 0.89 & 310 & 3.62 & 0.93 \\
\hline 11. & q11 & $\begin{array}{l}\text { Are you able to accept your bodily } \\
\text { appearance? }\end{array}$ & 172 & 3.64 & 1.05 & 310 & 3.90 & 0.82 \\
\hline 12. & q12 & $\begin{array}{l}\text { Have you enough money to meet your } \\
\text { needs? }\end{array}$ & 172 & 2.54 & 0.97 & 310 & 2.87 & 1.08 \\
\hline 13. & q13 & $\begin{array}{l}\text { Do you have access to the information } \\
\text { that you need in your day-to-day life? }\end{array}$ & 172 & 3.22 & 0.91 & 310 & 3.87 & 0.77 \\
\hline
\end{tabular}




\begin{tabular}{|c|c|c|c|c|c|c|c|c|}
\hline 14. & $\mathrm{q} 14$ & $\begin{array}{l}\text { Do you have the opportunity for leisure } \\
\text { activities? }\end{array}$ & 172 & 3.00 & 1.01 & 310 & 3.33 & 1.00 \\
\hline 15. & $\mathrm{q} 15$ & How well are you able to get around? & 172 & 3.04 & 0.96 & 308 & 4.27 & 0.84 \\
\hline 16. & $\mathrm{q} 16$ & How satisfied are you with your sleep? & 172 & 2.94 & 1.03 & 308 & 3.61 & 0.99 \\
\hline 17. & $\mathrm{q} 17$ & $\begin{array}{l}\text { How satisfied are you with your ability } \\
\text { to perform your daily living activities? }\end{array}$ & 172 & 3.12 & 0.83 & 308 & 3.76 & 0.78 \\
\hline 18. & q18 & $\begin{array}{l}\text { How satisfied are you with your capacity } \\
\text { for work? }\end{array}$ & 172 & 2.91 & 0.97 & 308 & 3.76 & 0.80 \\
\hline 19. & q19 & How satisfied are you with yourself? & 172 & 3.30 & 0.95 & 308 & 3.57 & 0.76 \\
\hline 20. & $\mathrm{q} 20$ & $\begin{array}{l}\text { How satisfied are you with your personal } \\
\text { relationships? }\end{array}$ & 172 & 3.64 & 0.91 & 308 & 3.75 & 0.91 \\
\hline 21. & $\mathrm{q} 21$ & How satisfied are you with your sex life? & 172 & 3.14 & 0.99 & 308 & 3.64 & 1.07 \\
\hline 22. & $\mathrm{q} 22$ & $\begin{array}{l}\text { How satisfied are you with the support } \\
\text { you get from your friends? }\end{array}$ & 172 & 3.67 & 1.02 & 308 & 3.85 & 0.80 \\
\hline 23. & $\mathrm{q} 23$ & $\begin{array}{l}\text { How satisfied are you with the } \\
\text { conditions of your living place? }\end{array}$ & 172 & 3.86 & 0.87 & 308 & 3.54 & 0.86 \\
\hline 24. & $\mathrm{q} 24$ & $\begin{array}{l}\text { How satisfied are you with your access } \\
\text { to health services? }\end{array}$ & 172 & 3.41 & 0.95 & 308 & 3.70 & 0.79 \\
\hline 25. & $\mathrm{q} 25$ & $\begin{array}{l}\text { How satisfied are you with your } \\
\text { transport? }\end{array}$ & 172 & 3.22 & 0.99 & 308 & 3.19 & 1.07 \\
\hline 26. & $\mathrm{q} 26$ & $\begin{array}{l}\text { How often do you have negative } \\
\text { feelings? }\end{array}$ & 172 & 3.59 & 0.80 & 308 & 3.47 & 0.95 \\
\hline
\end{tabular}

population - as compared to standard (control) population - had lower values, i.e. they perceived their physical health and quality of life as worse. The remaining 24 items (marked q3 through q26) are split in four domains.

The first domain (Dom1) is identified as physical health and comprises seven items (q3, q4, q10, q15, q16, q17 and q18). This domain takes into consideration three aspects of physical health and four aspects of physical independence.
The second domain (Dom2) is identified as psychological health and comprises six items (q5, q6, q7, q11, q19 and q26). This domain contains five aspects of psychological health and one independent aspect focusing on spirituality.

The third domain (Dom3) focuses on three aspects of social relationships. It comprises three items (q20, q21 and q22) and is identified as social relationships.

The fourth domain (Dom4) is identified as environment, comprising eight items 
(q8, q9, q12, q13, q14, q23, q24 and q25) concerning the environment.

Table 2 presents the score of domains and items Q1 and Q2 according to the age of the subjects.

Based on the table 2, it appears that, considering the age, the overall evaluation of the quality of life (Q1) and overall evaluation of the satisfaction with health (Q2), were decreasing with increasing age.
Table 3 presents the score of individual domains and independent items Q1 and Q2 according to the diagnosed duration of diabetes.

With respect to the defined goals of our work, very important are the results of the analysis of correlation between socio-demographic variables (age and duration of the subjects' disease) and individual domains including independent items Q1 and Q2 as listed in table 4.

Table 2 Mean score of domains and items Q1 and 02 according to the age of the subjects

\begin{tabular}{|l|l|c|c|c|c|c|}
\hline \multicolumn{2}{|c|}{ Domain } & $\begin{array}{c}\text { up to 40 } \\
\text { years } \\
(\mathbf{N = 2 4 )}\end{array}$ & $\begin{array}{c}\mathbf{4 1 - 5 0} \\
\text { years } \\
(\mathbf{N = 1 8})\end{array}$ & $\begin{array}{c}\mathbf{5 1 - 6 0} \\
\text { years } \\
(\mathbf{N = 2 6})\end{array}$ & $\begin{array}{c}\mathbf{6 1 - 7 0} \\
\text { years } \\
(\mathbf{N = 5 8})\end{array}$ & $\begin{array}{c}\mathbf{7 0 +} \text { years } \\
\text { (N=46) }\end{array}$ \\
\hline Domain 1 & Physical health & 15.57 & 11.81 & 12.66 & 11.65 & 9.19 \\
\hline Domain 2 & Psychological health & 15.61 & 13.85 & 14.97 & 14.23 & 12.00 \\
\hline Domain 3 & Social relations & 16.56 & 13.78 & 15.69 & 13.66 & 12.00 \\
\hline Domain 4 & Environment & 14.75 & 12.39 & 13.85 & 12.52 & 11.78 \\
\hline Q1 & Quality of life & 3.22 & 3.21 & 3.21 & 3.20 & 3.19 \\
\hline Q2 & Satisfaction with health & 2.77 & 2.77 & 2.76 & 2.76 & 2.75 \\
\hline
\end{tabular}

Table 3 Mean score of domains and items $\mathrm{Q} 1$ and $\mathrm{Q} 2$ according to the diagnosed duration of diabetes

\begin{tabular}{|l|l|c|c|c|c|}
\hline \multicolumn{2}{|c|}{ Domain } & $\begin{array}{c}\text { up to 5 } \\
\text { years } \\
(\mathbf{N = 5 6 )}\end{array}$ & $\begin{array}{c}\mathbf{6 - 1 0} \\
\text { years } \\
(\mathbf{N = 5 9 )}\end{array}$ & $\begin{array}{c}\mathbf{1 1 - 1 5} \\
\text { years } \\
(\mathbf{N = 2 6 )}\end{array}$ & $\begin{array}{c}\mathbf{1 5}+\text { years } \\
\text { (N=28) }\end{array}$ \\
\hline Domain 1 & Physical health & 11.43 & 12.32 & 11.31 & 11.43 \\
\hline Domain 2 & Psychological health & 13.76 & 14.55 & 12.40 & 14.43 \\
\hline Domain 3 & Social relations & 13.90 & 14.90 & 12.27 & 13.81 \\
\hline Domain 4 & Environment & 12.34 & 13.12 & 12.33 & 13.79 \\
\hline Q1 & Quality of life & 3.09 & 3.52 & 3.07 & 3.00 \\
\hline Q2 & Satisfaction with health & 2.54 & 3.05 & 2.73 & 2.71 \\
\hline
\end{tabular}


Table 4 Correlation of socio-demographic variables (age and duration of disease) and WHOQOL-BREF domains including independent questions Q1 1 and QQ2

\begin{tabular}{|l|c|c|c|c|c|c|}
\hline & $\begin{array}{c}\text { Q1 } \\
\text { Quality } \\
\text { of life }\end{array}$ & $\begin{array}{c}\text { Q2 } \\
\text { Satisfaction } \\
\text { with health }\end{array}$ & $\begin{array}{c}\text { Domain 1 } \\
\text { Physical } \\
\text { health }\end{array}$ & $\begin{array}{c}\text { Domain 2 } \\
\text { Psychologi- } \\
\text { cal health }\end{array}$ & $\begin{array}{c}\text { Domain 3 } \\
\text { Social } \\
\text { relations }\end{array}$ & $\begin{array}{c}\text { Domain 4 } \\
\text { Environ- } \\
\text { ment }\end{array}$ \\
\hline Age & -0.620 & -0.491 & -0.724 & -0.345 & -0.427 & -0.330 \\
\hline $\begin{array}{l}\text { Duration of } \\
\text { illness }\end{array}$ & -0.062 & 0.055 & -0.026 & -0.014 & -0.095 & 0.125 \\
\hline
\end{tabular}

From table 4 it is apparent that there is a statistically significant association between the diabetic patient's quality of life and their age. The quality of life and satisfaction with health decreases with increasing age. At the same time, the satisfaction with physical and psychological health, satisfaction with the quality of social relationships and environment is also decreasing. No statistically significant association was demonstrated between the quality of life of diabetic patients and duration of their disease. No association was demonstrated between the duration of the disease and the quality of their life. No association was found between the duration of the disease and variables that express the satisfaction with health, with physical and psychological health of the subjects, with the quality of their social relationships and the environment where they live.

\section{Key areas of preventive measures in relation to prevention of diabetic foot complications}

We evaluated the positions of the subjects on sixteen key areas of preventive measures aimed at the prevention of diabetic foot complications. We also compared the answers by gender. Chi-square test was used to compare the results in both populations (males/females) at significance level $\mathrm{P}=0.05$ (table 5).
Statistically significant differences in the preference in the most important areas of preventive measures aimed at the prevention of diabetic foot complications between men and women were confirmed in a total of 7 of 16 areas of preventive measures aimed at the prevention of diabetic foot complications. In nine areas statistically significant differences in the preferences of women and men were not confirmed.

\section{Discussion}

\section{Discussion about the quality of life of patients with diabetes}

According to Dragomerická and Bartoňová (2006, p. 9), nowadays, with increasing life expectancy and prevalence of chronic and lasting disorders, the main goal of medicine and nursing care is not the health or mere extension of the duration of life, but rather preservation or improvement of the quality of life. This is based on the definition of the World Health Organization that defines the quality of life as the subjective perception of the individual - of his/her position in life in the context of the cultural environment and in relation to his/her objectives, expectations, lifestyle and interests. Determination of the quality of life of a specific individual is a highly complex process based on various assessment scales, most commonly in 
Table 5 Comparison of responses in male/female populations (chi-square test)

\begin{tabular}{|l|l|c|c|c|}
\hline \multicolumn{1}{|c|}{ Areas of preventive measures } & chi & sv & P \\
\hline 1. & Regular inspection and checking of foot & 0.028 & 1 & 0.868 \\
\hline 2. & Care for foot skin and toenails & 4.195 & 1 & 0.041 \\
\hline 3. & Use of special toenail cutters (not manicure tools) & 0.198 & 1 & 0.656 \\
\hline 4. & $\begin{array}{l}\text { Provision of medicinal pedicure services (foot care services } \\
\text { provided by professional pedicurist) }\end{array}$ & 8.682 & 1 & 0.003 \\
\hline 5. & Regular washing of feet with lukewarm water & 1.284 & 1 & 0.257 \\
\hline 6. & Wearing cotton socks with medical rubber band & 0.259 & 1 & 0.611 \\
\hline 7. & No barefoot walking & 4.210 & 1 & 0.040 \\
\hline 8. & Using proper footwear & 1.890 & 1 & 0.169 \\
\hline 9. & Regular lower limb gymnastics (vascular gymnastics) & 12.120 & 1 & 0.000 \\
\hline 10. & Adequate overall physical activity & 0.198 & 1 & 0.656 \\
\hline 11. & Regular visits with diabetes specialist & 3.980 & 1 & 0.046 \\
\hline 12. & $\begin{array}{l}\text { Regular consulting and education of individuals with diabetes } \\
\text { on coping with the disease, with focus on prevention of foot } \\
\text { complications (such as injuries) }\end{array}$ & 1.186 & 1 & 0.276 \\
\hline 13. & Adherence to diet regimen & 1.697 & 1 & 0.193 \\
\hline 14. & Adherence to treatment regimen & 10.190 & 1 & 0.001 \\
\hline 15. & No smoking & 0.777 & 1 & 0.378 \\
\hline 16. & Increased care for diabetic patients by healthcare staff & 1 & 0.000 \\
\hline
\end{tabular}

the form of questionnaires (Cetlová et al., 2011, p. 7).

Using a standardized WHOQOL-BREF questionnaire, we compared the quality of life between our research population and a control set of common population according to the authors Dragomirecká, Bartoňová (2006, p. 22). On average, the overall quality of life and satisfaction with health was assessed by the subjects as lower than the population standard (table 1). Similar situation was observed also with respect to the domain of physical health, psychological health, social relationships and environment.

In our research, we found a significant association between the age and the quality of life of the patients (table 4). Correlation analysis of the acquired data demonstrated the inverse proportion (negative values of correlation coefficients) between the age and all areas of the patient's quality of life represented by domains - physical health $(-0.724)$, psychological health $(-0.345)$, social relationships $(-0.427)$ and environment (-0.330). A significant correlation was 
demonstrated also between age and overall quality of life (-0.620) and satisfaction with health $(-0.491)$.

Similar conclusions with respect to the quality of life in relation to the patient's age and with respect to the quality of life compared to population standard were reached also in the population subset of patients with diabetic foot syndrome in selected health centres in Moravian-Silesian region in the Czech Republic (Zeleníková et. al., 2014 , p. 4). When comparing the quality of life of the selected populations of diabetic patients and patients after lower limb amputation with the population norms, the authors - Bužgová, Hájková and Jasioková (2009, p. 249-250) point out the perception of reduced quality of life in these individuals compared to the common population. While the patients with a history of lower limb amputation demonstrated the lowest score of the quality of life in all areas, diabetic patients perceived reduced quality of life mainly in the area of physical health.

The research shows that the diabetic patients have lower quality of life compared to the patients without chronic disease (Yekta et al., 2011, p. 393). According to the French authors Valensi et al. (2005, p. 263), significant predicting factors of the reduced quality of life are the age, presence of type 2 diabetes and more advanced stage of diabetic ulcer. The presence of the diabetic foot syndrome reduces the patient's quality of life especially in the area of physical health.

\section{Discussion about the choice of the key areas of preventive measures in relation to prevention of diabetic foot complications}

Improved quality of life in diabetic patients is subject to their active involvement in their treatment (Závodná, 2005). Their interest in the collaboration with the team of diabetes specialists will initiate the effort to get their health under their control, preventing the need to treat complications. We were interested to know which areas of preventive measures aimed at the prevention of diabetic foot complications are the most important according to the subjects. Foot self-monitoring (regular inspection and checking of feet) is one of the most important areas according to the answers provided by the subjects in our research population. This area is preferred by up to $60.47 \%$ subjects $(61.29 \%$ male and $60.00 \%$ female $)$.

The importance of self-monitoring with respect to education of diabetic patients and subsequent improvement of diabetes control is also pointed out by Jirkovská (2006, p. 95-98).

We were also interested to know whether there are statistically significant differences in the choice of the most important areas of preventive measures preventing the complications of diabetic foot between men and women. In seven areas there are statistically significant differences in the preference for preventive measures between men and women (table 5). The men in our research population preferred especially the preventive measures related to no barefoot walking, adherence to treatment regimen and avoiding smoking. Women compared to men, more strongly preferred the care for skin and toenails of the foot, services of professional pedicurist, regular vascular gymnastics of lower limbs and regular visits with diabetes specialists. Men and women mostly agreed in the preference for regular inspection and checking of the feet.

The differences in the preference for individual preventive measures in relation to diabetes and in the extent of knowledge about this disease between men and women have been pointed out by authors Nemcová and Hlinková (2011, p. 8). They confirmed, that after education, women demonstrated 
a higher level of knowledge in the area of practising an inspection and care for the feet compared to men.

According to Poněšický (2003), men and women have different priorities, assign different importance to goals, and have differing skills, capabilities and techniques used to achieve these goals. In relation to their health, men overestimate themselves and engage in risky behaviour. This is one of the reasons for different views of diabetic patients - men and women on certain areas of preventive measures. As there are differences between men and women, appropriate techniques should be selected for nursing education based on these differences.

\section{Conclusion}

The search for options and methods aimed at improvement of the level of nursing care provided to diabetic patients with emphasis on the prevention of the amputation of the foot is not only a current topic attracting the attention of experts in different fields of research, it is also a topic associated with the improvement of the quality of life of people with this condition.

Diabetic patients are no more just passive recipients of care but also individuals who are active, more independent and jointly responsible for the achieved results. A very important aspect is the knowledge of the preventive measures focused especially on the prevention of the complications of a diabetic foot and access to quality education. Education in diabetes helps to take the attitude towards this incurable but very well controllable disease. The presented findings should be viewed as a contribution to the resolution of the problem of caring for people with diabetes, with emphasis on the prevention of foot amputation. The benefits of this work include not only the collected data on the quality of life of diabetic patients and their attitude towards preventive measures aimed at the prevention of diabetic foot complications but also the possibility of application of the outcomes in future research in similar areas.

\section{References}

1. BUŽGOVÁ R., HÁJKOVÁ M., JASIOKOVÁ A. (2009): Experience in measuring the quality of life with a questionnaire WHOQOL-BREF in selected groups of patients. Contact, no. 1, pp. 246-251, ISSN 1212-4117.

2. CETLOVÁ L., STANČIAK J., BĚHALOVÁ H. (2011): The quality of life in women with urinary incontinence. In Ižová M., Vicáňová M.: Family in health and disease. Proceedings of the international conference. Ružomberok: VERBUM, pp. 6-14, ISBN 978-80-8084-778-4.

3. DRAGOMIRECKÁ, E., BARTON, J. (2006): WHOQOL-BREF The WHOQOL-100. User Manual for users of the Czech version of the Quality of Life Questionnaire of the World Health Organization. Prague: Prague Psychiatric Center, 88 pp. ISBN 80-85121-82-4.

4. FARD D. et al. (2007): Assessment and treatment of diabetic foot ulcers. International Journal of Clinical Practice, vol. 61, no. 11, pp. 1931-1938, ISSN 1742-1241.

5. HOLMANOVÁ E., ŽIAKOVÁ K., ČÁP J. (2002): The impact of education on the quality of life of diabetic patients. Diabetes and obesity, vol. 2, no. 4. pp. 52-59. ISSN 1335-8383.

6. JIRKOVSKÁ A. et al. (2006): The diabetic foot syndrome. Prague: Maxdorf, $397 \mathrm{pp}$. ISBN 80-7345-095-X.

7. NEMCOVÁ J., HLINKOVÁ E. (2011): Education in the prevention of diabetic ulceration and amputation. Nursing: Theory, research, education, vol. 1, no. 1, pp. 5-11.

8. PONĚŠICKÝ J. (2003): The phenomenon of femininity and masculinity. Praha: Triton, 204 pp. ISBN 80-4254-350-4. 
9. VALENSI P. et al. (2005): Quality of life and clinical correlates in patiens with diabetic foot ulcers. Diabetes \& Metabolism, vol. 31, no. 3, pp. 263-271, ISSN 1262-3636.

10. YEKTA Z. et al. (2011): Comparison of demographic and clinical characteristics influencing health-related quality of life in patients with diabetic foot ulcers and those without foot ulcers. Diabetes, Metabolic Syndrome and Obesity: Targets and Therapy, no. 4, pp. 393-399. ISSN 1178-7007.
11. ZÁVODNÁ V. (2005): Education in Nursing. 2nd ed., Bratislava: Osveta. 117 pp. ISBN 80-8063-193-X.

12. ZELENÍKOVÁ, R. et al. (2014): Evaluation of the quality of life of patients with diabetic foot syndrome in selected health facilities Region. Nursing and Midwifery, vol. 5, no. 1, pp. 2-8, ISSN 1804-2740. 